\title{
GASTRIC CANCER. A FLEETING GLIMPSE AT ITS GENETIC EVIDENCES
}

Lopasso FP. Gastric cancer. A fleeting glimpse at its genetic evidences. Arq Gastroenterol. 2014;51(2):77-8.

HEADINGS - Stomach neoplams. Genetics.

Genetic and epigenetic alterations are involved in gastric cancer (GC) development and progression by activating growth-promoting pathways and inactivating tumor-suppressive pathways. Genetic alterations like point mutations as $p 53, K R A S, P I K 3 C A$, ARIDIA, MLL3 and MLL mutations, small insertions and deletions, chromosomal gains and losses, gene amplifications as PIK3CA,C-MET, ERBB4 and $C D 44$ are frequently found in GC, suggesting that they have a key and critical role in gastric human tumorigenesis. Epigenetic alterations enclose aberrant DNA methylation, histone modifications, nucleosome positioning, noncoding RNAs and microRNAs. Aberrant DNA methylation in the promoter region of gene (CpG island) is known to repress transcription of its downstream gene. Therefore, a tumor suppressor gene can be permanently inactivated by this mechanism.

GC is prevalently an epigenetic phenomenon in which more than $90 \%$ of the heritable alterations are of epigenetic origin. In the early steps of gastric carcinogenesis, for example, aberrant methylation caused by Helicobacter pylori (H. pylori) has also an extensive role ${ }^{(11,16)}$. Multiple factors besides bacterial infection, like dietary habits, smoking and genetic polymorphisms determine the risk of GC development. Various genetic aberrations and epimutations become critical during the initiation and progression of GC.

Today it is well recognized that a number of epigenetic abnormalities in intestinal metaplasia and adenoma are precursors of GC. This multistep pathogenesis of intestinal-type GC is an accepted paradigm but the pathogenesis of the diffuse type is not fully understood, despite of the role of $\mathrm{H}$. pylori infection, there are no known histologic precursor lesions of this type of GC. During the progressive stages of the GC carcinogenesis, $\mathrm{CpG}$ island hypermethylation and repetitive DNA hypo-methylation increase from chronic gastritis to $\mathrm{GC}^{(14)}$. The analysis of the profile of genetic / epigenetic alterations in
GC has provided new insights into the genes defaults and identifies molecular targets to the therapeutics approaches in selected patients. Within the profiles of these patients cohorts, recently, point mutations and gene amplifications of a large number of target genes can be analyzed by bench top next-generation sequencers $^{(6)}$, and a comprehensive DNA methylation can be analyzed using a bead array ${ }^{(3)}$, since these mechanisms are shown to be the most frequently observed causes of gene modification ${ }^{(16)}$.

In an integrated analysis of cancer-related pathways of 55 gastric cancers within the growth-promoting pathways, the $W N T$ pathway was activated only in two cases through mutations of the genes that encode $\beta$ catenina, but in 49 cases the activation was due to potentially aberrant methylation of its negative regulators, the $A K T / m T O R$ pathway was activated by mutations of its coding gene $P I K 3 C A$ in four cases and the $M A P K$ pathway was activated in 11 cases through mutations and gene amplifications of $E R B B 2$ and $K R A S^{(16)}$. In this study, between the tumor repressive pathways, the inactivation was observed in the cell cycle regulations in 13 cases by aberrant methylation of $M H L$ in two gastric cancers. The $\mathrm{p} 53$ was inactivated by mutations of $T P$ 53 in 19 of these GC and by potentially aberrant methylation of it downstream in 38 cases. The cell adhesion was affected by mutations of $C D H 1$ in two cases but none of the $50 \mathrm{GC}$ had heavy aberrant methylation of $\mathrm{CDH1}$; that is interesting because this suppressor gene is known to be important for the diffuse-type histology.

Familial clustering under a dominant inheritance causes $12 \%$ of gastric cancer ${ }^{(4)}$. Swedish database showed that when a parent had GC, the offspring risk was almost 1.6 fold increased only at ages older than 50 years, whereas the risk of probed siblings was near six fold increased, but only when the diagnosis was earlier than 50 years $^{(7)}$. These transmission patterns were probably environmental and seen according with the easier transmission pattern of $H$. pylori infection observed in siblings.

The author indicated no potential conflicts of interest

*Professor Livre Docente do Hospital das Clínicas da Faculdade de Medicina da Universidade de São Paulo, São Paulo, SP, Brasil 
Hereditary diffuse gastric cancer is an inherited gastric cancer predisposition syndrome that is associated with germline transmission of a $C D H 1$ mutation $^{(5)}$. Since there is $75 \%$ lifetime risk of developing diffuse-type gastric cancer in a gene carrier of this mutation, a prophylactic total gastrectomy should be considered when his or her age reaches the mid $20 \mathrm{~s}^{(1)}$.

Peculiar genetic features contribute to GC. Campanholo et al. ${ }^{(2)}$ in a report that accompanies this editorial studied one of them, the variant polymorphism-765 $\mathrm{G}>\mathrm{C}$ of the $C O X-2$ gene. Their original contribution refers to the increased association between the polymorphism in GC genotypes and the risk of GC in a suitable Brazilian cohort of the population. Interestingly, the hypomethylation status of $C O X 2$ gene was associated with the intestinal type GC in patients from northern Brazil independently of the status of $H$. pylori infection ${ }^{(12)}$ although it is well established that $H$. pylori contributes to $C O X-2$ expression in both $\mathrm{GC}$ and gastric IM adjacent to the cancer ${ }^{(15)}$.

In MALT lymphomas, apart from several somatic genetic aberrations, including trisomy $3, p 53$ mutation/LOH and $p 16$ deletion $^{(8)}$, some of which have shown to have diagnostic and prognostic value, five non-random chromosomal translocations involving few genes can be detected. These translocations appear to converge to the same nuclear factor kappa B (NF-kB) oncogenic pathway. Even so the lymphoma acquired as a result of $H$. pylori infection is histologically distinct from MALT lymphoma $H$. pylori independent, and that the eradication that leads to its regression can last from a few weeks to 18 months $^{(8)}$, it is very important the early definition of the therapeutic strategies. This is especially relevant since we know now that this independence is a feature of lymphoma progression coincident with the acquisition of additional genetic alterations ${ }^{(8)}$. In this setting, the article of Lima et al. ${ }^{(10)}$, published in this issue, reports the behavior of the most common structural chromosomal abnormality frequently found in gastric lymphoma, the translocation $\mathrm{t}(11 ; 18)(\mathrm{q} 21 ; \mathrm{q} 21)$ that results in a chimeric fusion between the API2 and MALTI genes ${ }^{(8)}$. As they conclude, the detection of this translocation may be critical for targeting the therapy since it is highly specific for MALT subtype; it has also a high diagnostic value and often is found in gastric MALT lymphoma patients infected with CagA-positive $H$. pylori $^{(8)}$. As the transcript is almost never found in MALT lymphoma with areas of high-grade transformation, some authors consider it restrict to low-grade cases $^{(9,13)}$. Others clinical relationships between the $t(11 ; 18)$ and MALT lymphoma include the association with advanced cases and submucosal involvement, but it is absent in lymphomas restricted to the mucosa ${ }^{(8,13)}$.

In summary, the emerging genetic knowledge related to clinical implications has been recently reported and will produce a steady upgrade on the targeted treatment of gastric malignancies.

Fabio Pinatel LOPASSO

Lopasso FP. Câncer gástrico. Um breve relance em suas evidências genéticas. Arq Gastroenterol. 2014;51(2):77-8.

DESCRITORES - Neoplasias gástricas. Genética.

\section{REFERENCES}

1. Blair VR. Familial gastric cancer; genetics, diagnosis and management. Surg OnAm. 2012;21:35-56.

2. Campanholo VMLP, Felipe AV, Lima JM, Pimenta CAM, Ventura RM, Forones NM. $-765 \mathrm{G}>\mathrm{C}$ polymorphism of the COX-2 gene and gastric risk in Brazilian population. Arq Gastroenterol. 2014;51(2):79-83.

3. Dedeurwaeder S, Defrance M, Calonne E, Denis H, Sotiriou C, Fuks F. Evaluation of the methylation 450K technology. Epigenomics. 2010;3:771- 84.

4. Goldgar DE, Easton DF, Cannon-Albright LA. Systematic population-based assessment of cancer risk in first-degree relatives of cancer probands. J Natl Cancer Inst 1994;86: 1600-8.

5. Guilford P, Hopkin J, Harraway J, McLeod M, MaLeod N, Harawira P et al. E-cadherin germline mutations in familial gastric cancer. Nature. 1998;392: $402-5$.

6. Gullapalli RR, Lyons-Weiler M, Petrosko P, Dhir R, Becich MJ, LaFramboise WA. Clinical integration of next-generation sequencing technology. Clin Lab Med. 2012;32: 585-99.

7. Hemminki K, Jiang Y. Familial and second gastric carcinomas: a nationwide epidemiologic study from Sweden Cancer. Cancer. 2002;94: 1157-65.

8. Isaacson PG. Update on MALT lymphomas. Best Pract Res Clin Haematol. 2005; 18: 57-68

9. Li BZ Lu HF, Zhou XY, Yang WT, Kong YY, Fan YZ, Shi DR. Frequency of genetic aberrations in mucosa associated lymphoid tissue lymphoma of different sites. Zhonghua Bing-Lixue Zazhi. 2008;37: 604-8.
10. Lima KS, Albuquerque W, Arantes VN, Drumond-Lage AP, Coelho LGV. Helicobacter pylori and $\mathrm{t}(11 ; 18)(\mathrm{q} 21 ; \mathrm{q} 21)$ translocation in gastric malt lymphoma. Arq Gastroenterol. 2014;51(2):84-9

11. Maekita T, Nakazawa K, Mihara M, Nakajima T, Yanaoka K, Iguchi M. et al High levels of aberrant DNA methylation in Helicobacter pylori-infected gastric cancer mucosae and its possible association with gastric cancer risk. Clin Cancer Res. 2006;12: 989-95.

12. Melo CFV, Gigek CO, Silva JN, Smith MAC, Araujo RM, Burbano RR, Lima EM. Association of COX2 gene hypomethylation with intestinal type gastric cancer in samples of patients from northern Brazil. Tumor Biol. 2014; 35:1107-11.

13. Nakamura S, Matsumoto T, Nakamura T, Jo Y, Fujisawa K, Suekane H, Yao T, Tsuneyoshi M, Iida M. Chromosomal translocation $\mathrm{t}(11 ; 18)(\mathrm{q} 21 ; \mathrm{q} 21)$ in gastrointestinal mucosa associated lymphoid tissue lymphoma . J Clin Pathol. 2003; $56 ; 36-42$.

14. Oue N, Oshino Y, Nakamura H, Ito R, Yoshida K, Matsusaki K. et al. DNA methylation of multiple genes in gastric carcinoma: association with histological type and CpG island methylator phenotype. Cancer 2003; 94: 901-5.

15. Sun JH, Das KK, Amenta PS, Yokota K, Watari J, Sato T, Kohgo Y, Das KM. Preferential expression of cycloxigenase -2 in colonic-phenotype of gastric intestinal metaplasia: association with Helicobacter pylori and gastric carcinoma. $\mathbf{J}$ Clin Gastroenterol. 2006;40: 122-8.

16. Yoda Y, Takeshima H, Niwa T, Kim JG, Ando T, Kushima R, Sugiyama T, Katai $\mathrm{H}$, Noshiro H, Ushijima T. Integrated analysis of cancer-related pathways affected by genetic and epigenetic alterations in gastric cancer. Gastric Cancer 2014; Feb 9.[Epub ahead of print] accessed 04/07/2014. 